The poor meet the rich

\author{
'Nature' correspondents report \\ from Vienna on the opening \\ sessions of the United Nations \\ Conference on Science and \\ Technology for Development
}

\section{Third World: we will negotiate}

DELEGATES to UNCSTD from a wide range of Third World countries agreed at a meeting in Bucharest last week that, at least at the start of the conference, they will bury economic and ideological differences behind a common negotiating strategy. They also agreed to stand firm behind the developing countries' proposals for a draft plan of action to emerge from UNCSTD although they are prepared to negotiate on the plan's main demands rather than invite confrontation by sticking to a hard line.

The meeting was organised by the Group of 77 which has been negotiating on behalf of over 120 developing countries during the UNCSTD preparatory meetings. Representatives from the developed countries were relieved to hear that the Group of 77 would not seek initial confrontation. Although the developed countries are not prepared to accept all the demands that the developing countries have included in the proposed plan of action, they are keen, for political and economic reasons, to engineer a successful outcome to the conference.

Before the Bucharest meeting, some developing countries had complained that the proposed draft plan did not reflect their particular concerns. (The draft is the basis for the negotiations currently taking place in Vienna). Some African countries, for example, had complained that the proposals were too heavily weighted towards measures to benefit the more advanced of the Group of 77 countries - for example, with conditions governing technology transfer - and would not do enough to meet the technical needs of the poorest countries.

The Bucharest meeting agreed to recommend that the plenary session in Vienna establish a special working group to look at proposals for areas in which greater scientific and technical effort should be focused. In return the African groups agreed to support the Group of 77's proposals for a new funding system and new institutional arrangements for science and technology with the UN. Both proposals will be examined by UNCSTD's two main committees.

Members of the Group of 77 still differ,

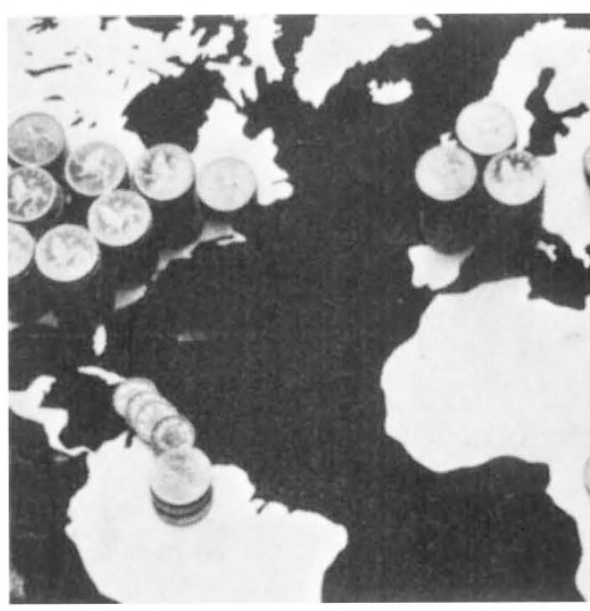

however, over how the new institutional arrangements would operate to assure the politically weaker countries adequate control over research funds and their application.

A statement summarising the demands of the plan of action was issued at the end of the meeting. It says that inequalities in all fields of international economic relations are especially actue in science and technology. Despite the efforts of the developing nations there has been no real progress towards setting up a New International Economic Order with science and technology forming an intergral part. The statement expresses alarm at the large fraction of global research expenditure devoted to defence and asks for "free and full access to scientific and technical knowledge, discoveries and innovations".

International cooperation should also play an important part in harnessing science and technology to the social objectives of the developing countries, the statement says. "For this, global and fundamental structural changes are required in the existing distribution of scientific and technological capacities in the world, in order to ensure increased participation by the developing countries in the quest for new scientific and technological knowledge',

In line with the suggested plan of action, the statement urges that international law governing technology transfer should be "restructured" in line with the goals of the developing countries who should be able to participate in financing mechanisms set up for scientific and technological development. The statement also urges support for measures to increase scientific and technical cooperation between developing countries. It says that practical measures "should be undertaken to support the cause of national liberation of peoples and territories under foreign occupation, control and domination, racism and racial discrimination, to enable them also to benefit from the application of science and technology for their development".

David Dickson

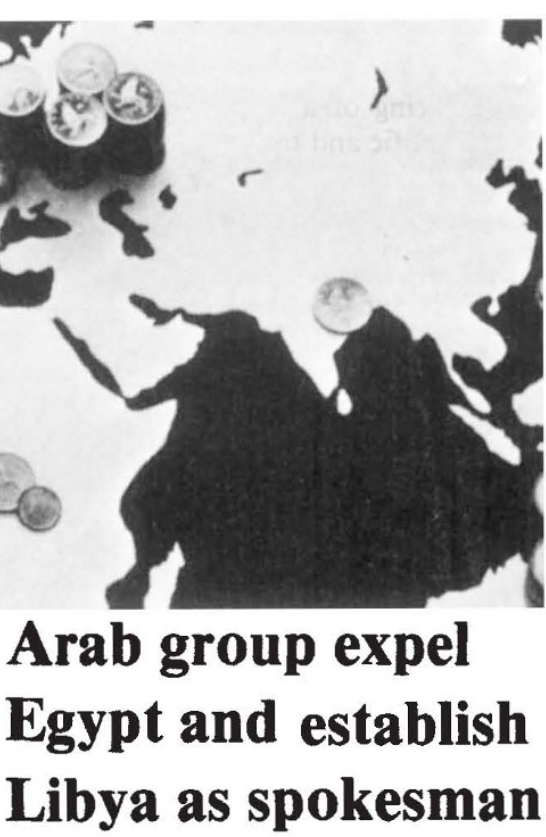

The decisions taken at the Tenth Conference of Islamic Foreign Ministers, held in Fez during April, are now being implemented by a strong 'Arab group' that has emerged at UNCSTD. The Islamic conference decided to boycott Egypt on all issues and support the Palestine Liberation Organisation.

In the past Egypt has assumed a natural leadership on Arab issues, in the field of science and technology, and this is the first time it has faced a determined and joint opposition to its efforts to lead the Arab group. Libya was unanimously elected to lead the group last week-end despite the fact that, nominated as a vice-president for North Africa, it was absent from its first meeting.

Alienation of Egypt from the Arab group has provided even stronger Arab support for the PLO delegation to UNCSTD. "We are determined to get a nation-state status for the PLO' ' a member of the Syrian delegation declared. At their first meeting, the group decided not to articulate an OPEC (or more appropriately, AOPEC) position. OPEC Arab countries will play a low-key role where we are allowed to do so" and will merge their identities within the Arab group.

The group also decided to give full support to the announced position of the Group of 77 . Although the stance taken by the Group of 77 is a little too radical for some of the more conservative Arab states, like Saudi Arabia, Kuwait and the UAE, these states have been pursuaded to support the Group of 77 as much as possible. Similarly Syria, which has shown considerable opposition to some declarations of the Group of 77, has decided to overlook its objections and support the decisions of the Arab group. Dr Shakir Fahm, Syrian Minister of Higher Education and leader of the Syrian delegation to UNCSTD says, "now is the time for the developing countries to show 
their strength. This strength lies in unity'.

What the Arab group did not discuss is the financing of a development fund to help scientific and technological activities in the developing countries. Whether Saudi Arabia and other oil-rich Arab states will back such a fund to the tune of $\$ 65$ million a year for the first two years of the fund, as some suggested, they did not decide though there is some indication that Saudi Arabia will give in to the US pressure. The Saudi aid to developing countries granted through the Saudi Development Fund, far exceeds this sum in an average year. The Saudi decision to support the fund, if it is forthcoming, will therefore be in line with their aid policies.

In addition to national efforts in such countries, international cooperation can and should play an important part, the statement says. "For this global and fundamental structural changes are required in the existing distribution of scientific and technological capacities in the world, in order to ensure increase participation by the developing countries in the quest for scientific and technological knowledge."

Ziauddin Sardar

\section{'In everyone's}

\section{interest' to}

\section{transfer technology}

The transfer of technology is not an issue of necessary conflict between developed and the developing countries, according to Crown Prince Hassan of Jordan, who shoulders the responsibility for social and economic planning in Jordan. Speaking during the general debate of the second plenary meeting at UNCSTD, Prince Hassan said that "despite short term disagreements and apparent disparities, in the long term, technology transfer is in everybody's interest". He warned, however, that technology "is not a commodity which can be copied to exaction. The transferred technology has to be appropriate to the needs of the receipient country".

Many developing countries, said the Prince, lack the basic conditions for the establishment of agencies that promote and enhance technology. Furthermore, technology in the developed countries is based on a particular concept of entrepreneurship - that motivated by economic and commercial considerations. The Prince questioned the desirability of the developing countries adopting such a concept and argued for a "spirit of resourcefulness" or "appropriate entrepreneurship".

The Prince pointed out that at present much aid is channeled towards the poorest members of the Third World, the decisions for granting aid being made on the basis of gross national product (GNP). But there is hardly any relationship, argued the prince, between GNP per capita and the levels of development.

\section{Waldheim attacks'wasteful}

\section{consumerism'}

A major task of UNCSTD is to help generate universal acceptance of the need to direct the use of humanity's scientific and technological potential to constructive ends, Dr Kurt Waldheim, Secretary General of the United Nations, told the opening session of the conference on Monday morning.

In a speech which reflected many of the ideas put forward by the conference secretariat during the preparatory process, Dr Kurt Waldheim singled out three areas in which he claimed much of human ingenuity and innovative ability had been misdirected into areas not beneficial for mankind: military technology; a type of economic growth which ignored damage to the environment or the social and cultural fabric; and the support of "wasteful consumerism in a world where famine and malnutrition are tragically present".

Another motivating factor behind the conference was the enormous imbalance in research and development being undertaken internationally, he said, resulting in developing countries having to depend excessively on imported technology. This hampered the growth of indigenous skills more harmonious with local conditions and socials or economic needs.

"This becomes a self-generating process and breeds over-all dependence. The starting point for breaking this circle is to enable the developing countries to gather and share the scientific knowledge so as to enhance their technological capabilities and accelerate their development", he said.

Talking of the brain drain, the Prince emphasised that the human dimensions of the problem, "which have a direct bearing on technological and scientific development in both labour-exporting and labourimporting countries", are often overlooked.

Crown Prince Hassan suggested that the labour exporting countries should turn the situation to their advantage through policies that aim to utilise the experience of their nationals working abroad. "These should take the form of annual feedback programmes, where highly trained scientists and technologists working abroad would come back to their countries for varying lengths of time"'.

Making an obvious reference to the proposed global development fund, the prince said that "we have to be careful before we decide to create yet another international agency providing yet another variation on the existing manner of solving an already identified problem".

Ziauddin Sardar
Three elements were crucial in designing a successful programme of action: a conscious political will, increased funding for science and technology at the national and international levels, and the institution of an efficient mechanism for this purpose. Finally, directly echoing words used on many occasions by conference SecretaryGeneral Mr Frank da Costa, Dr Waldheim said that the real divisions in the world were not between the north and south or east and west, but between those in favour of a passive continuation of the status quo, "which is prejudicial to all" and those in favour of dynamism, changes and innovation. "Let this conference signal the fact that science and technology can unite the developed and the developing countries in the common cause of the world's future as a whole", Dr Waldheim said.

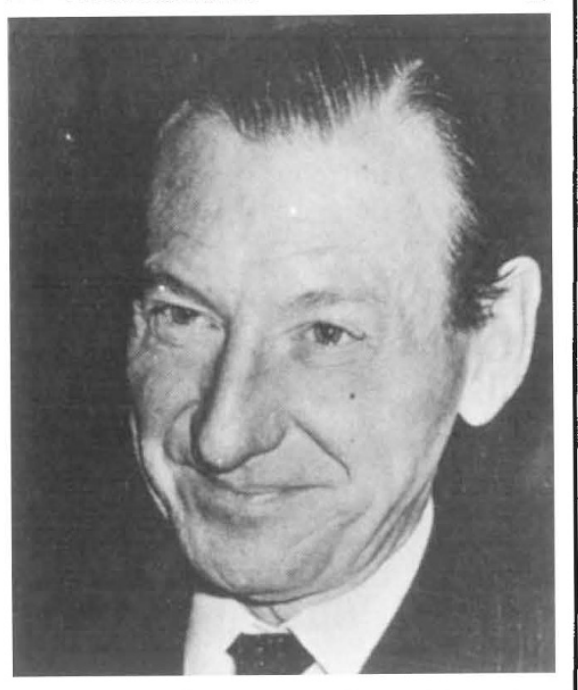

\section{Britain opposes creation of new \\ mechanisms}

A greater proportion of national and international aid budgets should be devoted to scientific and technological aspects of development, but there is no need at present for new financing mechanisms or institutional arrangements to do this. Such was the main message of the British delegation's contribution to the UNCSTD plenary debate on Wednesday morning.

Mr Neil Marten, UK Minister for Overseas Development, told the assembled delegates that, if developing countries so wished, Britain would be prepared to devote an increasing share of its bilateral aid programme to scientific and technological activities in the Third World. $\mathrm{He}$ also announced that Britain is considering plans to set up a technology transfer centre to act as a general switch- 